\title{
New Estimates of 24-Hour Probable Maximum Precipitation (PMP) for the British Isles
}

\author{
Colin Clark ${ }^{1}$, James Dent ${ }^{2}$ \\ ${ }^{1}$ Charldon Hill Research Station, The Batch, Shute Lane, Bruton, Somerset, UK \\ ${ }^{2}$ Laxfield House, Cundy's Lane, Brent Eleigh, Suffolk, UK \\ Email: colin4chrs@hotmail.com, dent650@btinternet.com
}

How to cite this paper: Clark, C., \& Dent, J. (2021). New Estimates of 24-Hour Probable Maximum Precipitation (PMP) for the British Isles. Journal of Geoscience and Environment Protection, 9, 209-228. https://doi.org/10.4236/gep.2021.97014

Received: May 22, 2021

Accepted: July 26, 2021

Published: July 29, 2021

Copyright () 2021 by author(s) and Scientific Research Publishing Inc. This work is licensed under the Creative Commons Attribution International License (CC BY 4.0).

http://creativecommons.org/licenses/by/4.0/ (c) (i) Open Access

\begin{abstract}
Estimates of PMP are needed in order to estimate the spillway design flood for dams which must be capable of safely passing the probable maximum flood (PMF). For over forty years the standard estimates of the Flood Studies Report (FSR) have almost always been used. However, since then several studies have shown that these values are too low, and new estimates for South West England and then Britain were published. This paper extends these studies to include the whole of the British Isles. The study uses 6570 station years' data in a new method of frequency analysis that identifies part of the data which represents the long term situation. Further analyses to support the results of this approach have been produced from the in situ maximisation of 12 historic storms using World Meteorological Organisation methods. The results are broadly consistent with those obtained from frequency analysis. Values of 24 hour PMP in Britain range from $600 \mathrm{~mm}$ in upland areas of the Lake District, to $400 \mathrm{~mm}$ in parts of East Anglia. This range of values is present in Wales and parts of South West England. For Ireland the highest values are over the upland areas, such as in the Wicklow Mountains $(550 \mathrm{~mm})$ and SW Ireland $(600 \mathrm{~mm})$, while in the lowlands values around $350 \mathrm{~mm}$ can be expected. The question of uncertainty in estimating PMP is considered, most of which is due to the temporal and spatial shortcomings of the data. The implications for the probable maximum flood (PMF) and spillway design flood mean that widespread reassessment of dam safety should be carried out at once.
\end{abstract}

\section{Keywords}

Probable Maximum Precipitation, Moisture Maximisation, Modified Gumbel Reduced Variate 


\section{Introduction}

Worldwide about one-third of all dam failures are due to overtopping following a major storm (Lemperiere, 1993). In Britain alone Hughes et al. (2000) reported that there have been 14 dam failures, 12 of which caused the loss of life. Since then there have been several near misses, including Boltby in 2005 (Clark, 2008). However, since 1925 when Coedty dam failed and 16 people were drowned, there has been no loss of life (Hughes et al. 2000). This incident led to legislation for dam safety assessments, followed by the Institution of Civil Engineers interim report on floods and reservoirs (ICE 1933). This was later reprinted with additional data (ICE, 1960). Publication of the Flood Studies Report (NERC, 1975) included estimates of PMP which are still being recommended for use in dam design and safety assessment (ICE, 2015). This latter publication is the fourth edition of a guide on the estimation of spillway design floods and dam safety assessments. Although the rainfall of lower rarity than PMP has been published (Institute of Hydrology, 1999, Stewart et al. 2013) no reassessment of PMP for the whole of the UK or British Isles has been produced. In a nationwide survey of historic dam incidents (Charles et al. 2011) identified exactly 100 UK cases. This figure excludes two which occurred during construction. Of the remainder 15 took place after the 1930 Reservoir Act, and of all events which involved overtopping, seven were post 1930. The Whaley Bridge incident of 2019 did not involve overtopping but was flood related. Their survey clearly shows a potential for serious overtopping in the future since none of the known events were caused by a PMP event as suggested by the Flood Studies Report and certainly not by the present findings.

In the past 25 years there have been several studies which have shown that FSR estimates are too low (Collier \& Hardaker, 1995, Clark, 1995, 2002), while Clark (2016) gives a list of events which have exceeded the FSR values, including a fall of $355 \mathrm{~mm}$ in 14 hours when the 24 hour FSR PMP was only $300 \mathrm{~mm}$. Alternative estimates have been provided for Britain (Clark, 2002) but not for the British Isles. The only attempt to reconcile the differences of PMP on the PMF came about with a reassessment of the spillway design flood of Bruton dam, where it was necessary to increase values of PMP over the range $2-24$ hours by a factor of about $1.25-1.37$ respectively. This, together with a decrease in the time to peak of the Unit Hydrograph and an increase in the percentage runoff, allowed a realistic estimate of the median flood, and a close comparison with a 240 year historic based flood frequency analysis (Clark \& Pike, 2007). As result the spillway design flood was increased from $240 \mathrm{~m}^{3} \cdot \mathrm{s}^{-1}$ to just over $500 \mathrm{~m}^{3} \cdot \mathrm{s}^{-1}$. An analysis for the upper Stour at Bourton in Dorset UK came to a similar conclusion (Clark, 2015). Given that there are about 2500 large regulated reservoirs in the UK and more being constructed mainly for flood storage (Faulkner \& Benn, 2016) it is essential that a revision of PMP standards are made. The main purpose of the present study is to provide new estimates of 24 hour PMP which can be used to design dam spillways that are able to safely pass the probable maxi- 
mum flood (PMF). Although PMP values in excess of Flood Studies Report (NERC, 1975) have been used to upgrade one dam in the UK a higher standard of PMP is needed for the whole of the British Isles since many of the +3000 dams are earth filled and many are over 100 years old.

\section{Methods of PMP Estimation}

There are several methods that can be used to estimate PMP and these have been described in the World Meteorological Organisation manual (WMO, 2009). These are listed below.

1) Statistical methods such as Chow (1951) and Hershfield (1961), with modifications (Desa et al., 2001; Afzali-Gorouth et al. 2018).

2) Hydrometerological methods using moisture maximisation and transposition such as Wiesner, 1970, Rakhecha and Clark (1999), Casas et al. (2011), Ishida et al. (2015).

3) Generalised methods using depth duration data, for example Rakhecha and Kennedy (1985), Australian Bureau of Meteorology (2003).

4) Empirical formulae from historic storms for example Clark (1995), WMO (2009).

5) Storm models such as Austin et al. (1995); Chavan and Srinavas (2015), Hiraga et al. (2021).

All of these methods have their strengths, weaknesses, and uncertainties. Ben Alaya et al. (2018) have shown that all methods have some subjectivity and show that a range of values should be given to take account of the uncertainty that exists. However, it has been shown that the Hershfield method for India is not appropriate. The Indian Institute of Tropical Meteorology (1989) used this method to estimate one-day PMP for India, giving a value of $700 \mathrm{~mm}$ for the Mumbai area. Rakhecha and Clark (1999) used depth area analysis in order to compensate for the low raingauge network and then the physical method of moisture maximisation. The result was $1200 \mathrm{~mm}$ for Mumbai. The difference was to some extent settled by the storm of $25^{\text {th }}$ July 2005 which had a one-day depth of 944 $\mathrm{mm}$. Further difficulties with more recent research include the failure to mention the density of the raingauge network (Ben Alaya et al., 2018) who produced estimates with a resolution of about $700 \mathrm{~km}^{2}$ which may fail to account for concentrations of very high rainfall and was the main motive to apply depth area analysis for Indian storms which were based on a similar raingauge density network (Rakhecha \& Clark, 1999). Another common drawback is that some studies fail to give storm details (Thanh Thuy et al., 2019) so that verification of their results cannot take place. There is also a dependence on model studies to estimate future temperature and precipitable water with the assumption that current estimates of PMP may already be too low (Rastogi et al., 2017). There is also no indication of the areal characteristics of PMP which are based on actual storms and how this may change in the future, although the WMO (2009) manual gives an example of enveloping curves of depth area duration data. 
In this study two methods are used. The first is a statistical analysis of annual maximum one-day rainfall; the second is the moisture maximisation procedure (WMO, 2009). In the first approach the search for a representative part of the data follows the use of rank-size analysis (Clark, 2019a). This has been shown to produce realistic estimates of both extreme rainfall and floods, in particular using data available up until 1990 before higher estimates for the American River in California which were produced after the flood of 1997. Further evidence for very high rainfall that was missed by the official raingauge network is also presented on historic storms, in particular the Martinstown storm of 1955 (Clark, 2005), the Dublin storm of 1963 (Clark, 2019b) and Norfolk 2020 storm (Holley et al., in press).

\section{Data and Methods}

The annual maximum from 139 sites in the British Isles was gathered from the British Atmospheric Data Centre website and from Met Eireann of which 135 were suitable for analysis. A total of 6570 station years data were used and included 12 historic storms were found that were maximised according to WMO methods. Figure 1 shows the distribution of the sites and historic storms. Table 1 shows the percentage distribution of elevation of land and the raingauges in Ireland and Britain wherein it is seen that all classes of elevation have a representative number of sites. However, there are very few sites above $300 \mathrm{~m}$ and this may obscure details of rainfall in areas known to be much wetter than the lowlands.

In this study two methods have been used to estimate 24 hour PMP. The first is a frequency analysis using a rank size method and modified Gumbel scale. The second method is the maximisation of 12 major historic storms, the results of which are then used to support those from the frequency analysis. The first method of analysis has been described by Clark (2019a). Data that are used in flood frequency analysis are assumed to be independent and identically distributed random variables (Klemes, 2000). In fact hardly any study checks this assumption by visual examination of a frequency plot and then by the use of Rank-Size Analysis. The latter method examines the data with return periods in the range of about $1.1-4.5$ years. Figure 2 gives an example of a rank size plot for Sandringham in Norfolk UK, where the annual maximum data are ranked and plotted against rainfall depth in order to identify a part of the data which are close enough to being described as identically distributed which is manifest in being aligned in a straight line. The return period is estimated using the empirically checked equation of Clark (1983):

$$
\text { Return period }=N(M-0.3)
$$

where $N=$ sample size and $M=$ rank order

The data range of return period of about $1.1-4.5$ years is likely to show, if it exists at all, a representative part of the data which can then be extrapolated to higher return periods. The resulting rainfall frequency equation is then used 


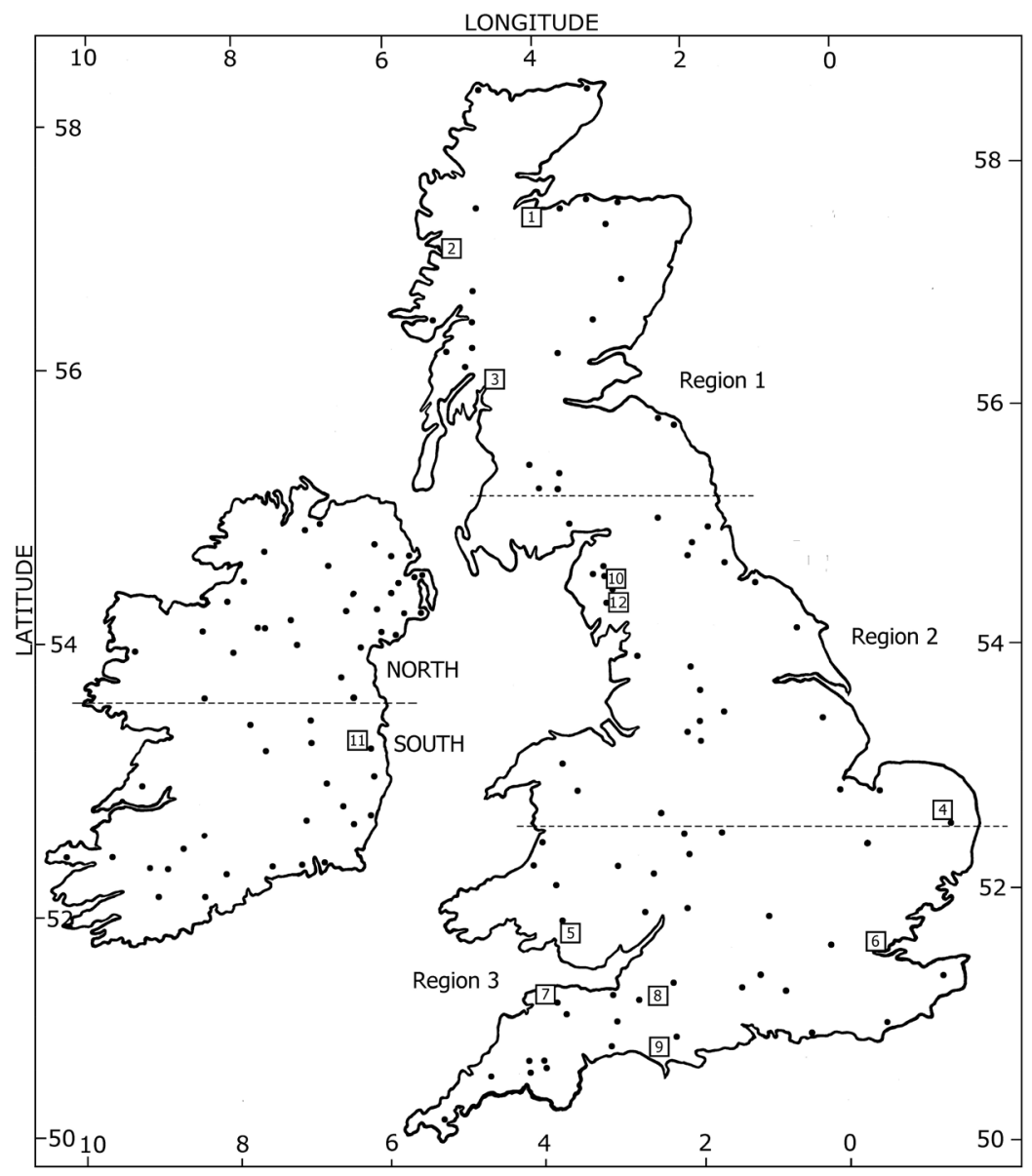

Figure 1. Location of rainfall stations in the British Isles used in this study.

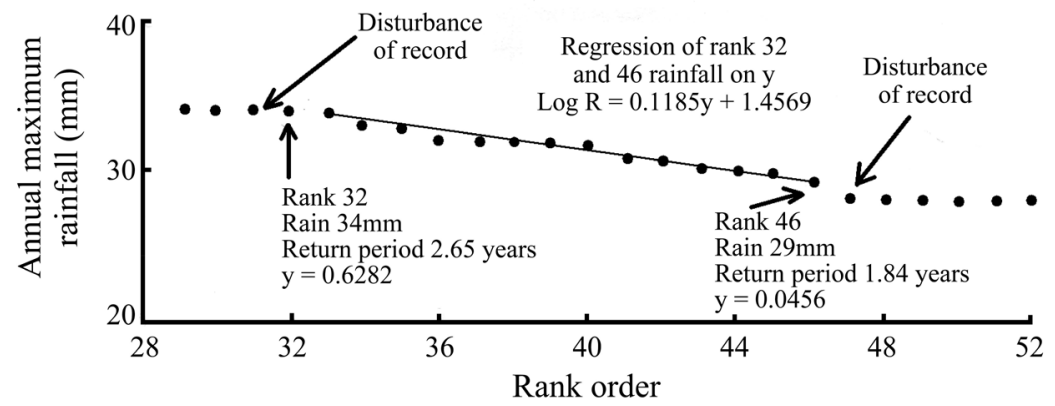

Figure 2. Rank size analysis of Sandringham UK rainfall.

Table 1. Distribution of land elevation and raingauges in Ireland and Britain.

\begin{tabular}{ccccc}
\hline & \multicolumn{2}{c}{ cumulative \% land ${ }^{*}$} & \multicolumn{2}{c}{ cumulative \% raingauges } \\
\cline { 2 - 5 } & & & (number of gaues in brackets) \\
\hline Height $(\mathrm{m})$ & Ireland & Britain & Ireland & Britain \\
$0-100$ & 58 & 58 & $67(37)$ & $51(41)$ \\
$101-200$ & 88 & 88 & $89(12)$ & $75(19)$ \\
$201-400$ & 99 & 99 & $96(4)$ & $90(18)$ \\
$401-1000$ & 100 & 100 & $100(2)$ & $100(2)$ \\
\hline
\end{tabular}

* values rounded to the nearest whole number. 
with the extreme frequency scale of Rakhecha and Clark (1999) in order to estimate the likely maximum rainfall which is assumed to have a return period of $10^{6}$ years (Lowing \& Law, 1995; Nathan et al., 2016).

$$
y=\left[(-\ln (1-1 / T 1)-3.3842) \times 1.09348 T^{-0.046518}\right]+3.3842
$$

where $T=$ return period (years).

Using a value of $y=9.3826$ for a return period of $10^{6}$ years in the equation in Figure 2 gives an estimate of PMP of $370 \mathrm{~mm}$. This result is converted into a 24 hour value by the factor of 1.16 (Institute of Hydrology, 1999). Thus the 24 hour PMP for Sandringham is $430 \mathrm{~mm}$.

It was not always possible to use the method for some sites such as Birkside in Northumbria, England because a representative part of the data could not be identified. All results were multiplied by the factor of 1.16, the ratio of 24-hour to 1 day rainfall. The results are related to the annual average rainfall for 1940-1970. The effect of latitude is discussed below.

Storm maximisation of the 12 major storms is obtained by using the 12-hour persisting dewpoint of the storm and a frequency analysis of at least 20 years dewpoint temperatures 15 days either side of the storm date. From these data the 100-year persisting dewpoint temperature is estimated (WMO, 2009). The moisture maximising factor (MMF) is the ratio of the maximum precipitable water $(\mathrm{pw})$ and the storm precipitable water multiplied by the storm rainfall depth:

$$
M_{\text {rain }}=R[\mathrm{Mpw} / \mathrm{Spw}]
$$

where $M_{\text {rain }}=$ maximised rainfall;

$\mathrm{Mpw}=$ maximum 12 hour persisting precipitable water;

$\mathrm{Spw}=12$-hour persisting precipitable water during the storm;

$R=$ storm rainfall.

The precipitable water or depth of water that the atmosphere can hold is related to air temperature and assumes a saturation adiabatic lapse rate for the depth of uplift. Data in WMO (2009) show an exponential increase in pw with temperature. Maps show the distribution of pw to be broadly related to latitude (Henderson-Sellers \& Robinson, 1986). The world catalogue of extreme rainfall shows the importance of this fact (WMO, 2009). Britain covers a latitudinal range of $8.7^{\circ}$ while for Ireland it is $3.87^{\circ}$. Therefore the data for Britain were analysed in three parts as shown on Figure 1, namely with average latitudes of $56.95^{\circ} \mathrm{N}$ for region $1 ; 53.95^{\circ} \mathrm{N}$ for region 2 , and $51.3^{\circ} \mathrm{N}$ for region 3 . The island of Ireland is divided into two parts, with average latitudes of $54.4^{\circ} \mathrm{N}$ and $52.5^{\circ} \mathrm{N}$ respectively. For Ireland there was only one historic storm, that of $25-6^{\text {th }}$ August 1986 (Wallingford, 1996). This is because of the much lower raingauge density (Clark, 2019b), with one gauge per $146 \mathrm{~km}^{2}$ in Ireland and one gauge per $86 \mathrm{~km}^{2}$ in Britain. For the southern half of Ireland the value is one every $137 \mathrm{~km}^{2}$. Pro Rata according to area, Ireland should have received about four 24 hour historic storms in excess of $200 \mathrm{~mm}$, but only one has been recorded.

Much has been written about the accuracy of rain gauges (Rodda \& Smith, 
1986; Rodda \& Dixon, 2012; Pollock et al., 2018). The main problem is under recording, especially in upland areas. The problem can be summed up by: "Anyone who has stood out in suffocating torrential rain and observed water splashing out of a standard raingauge funnel is, like me, quite likely to believe that the gauges understated the precipitation" (Cochrane, 1991). Rodda and Dixon (2012) compared ground level and standard raingauge data and have provided a map of the UK showing that upland areas under record by about $10 \%$ and the remainder by about 5\%. Although a $10 \%$ difference in parts of Somerset is indicated by this relationship there are no data to support the claim. At Charldon Hill Research Station in East Somerset the difference is only 1\% while for North Brewham which is $55 \mathrm{~m}$ higher it rises to $5 \%$. Wind is the chief factor for under estimating rainfall. There is as yet no method that obtains the true value. In some catchments in Scotland there can be more runoff than rainfall, proof of an undercatch of the true depth (Clark, 2016). For three successive years for the river Irt at Galesyke there was $226 \mathrm{~mm}$ more runoff than rainfall, but the true under catch is unknown. In view of these facts an additional $10 \%$ has been added to upland areas in excess of $400 \mathrm{~m}$ and $5 \%$ to all other areas.

\section{Results}

Figure 3 and Figure 4 show the relationship between PMP estimate and annual average rainfall (AAR) for 1940-1970 for Britain and Ireland respectively. Table 2 shows the regression equation for the three regions in Britain.

Figure 3 shows that the highest values of PMP are in Region 3 with a steady increase from about $400 \mathrm{~mm}$ in areas of AAR of $550 \mathrm{~mm}$ rainfall to about 550 $\mathrm{mm}$ in areas with over $2000 \mathrm{~mm}$ rainfall. Area 2 has a lower rate of increase of PMP with AAR: typically an area with $2000 \mathrm{~mm}$ AAR has an estimated PMP of $450 \mathrm{~mm}$. Region 1 follows the same pattern with an even lower rate of increase so that in the wettest areas PMP values are in excess of $400 \mathrm{~mm}$. In Figure 3 a higher correlation between AAR and PMP could not be expected because of the uncertainty in both the rainfall data and the method of analysis. If we had precise values for the annual maximum rainfall for a longer and more representative time period then the scatter on Figure 3 may be reduced. Consistent information on detailed site locations, maintenance of equipment, and accuracy of the measurement process are unknown. However, overall these results are consistent enough with the expectation of both convectional and orographic rain producing processes that cause the highest storm depth to be applicable for further analysis. This is supported by the results of three t tests between $\mathrm{N}$ and $\mathrm{S}$ Ireland PMP values $(t=21.1$, sig. $>0.1 \%)$ and between region 1 and 2 of Britain $(t=21.00$ sig. $>0.1 \%)$ and region 2 and $3(t=16.73$ sig. $>0.1 \%)$.

Table 2. Regression equations for the three regions in Britain.

\begin{tabular}{ll}
\hline Region 1 & $\mathrm{PMP}=0.02139 \mathrm{AAR}+327.6193 \mathrm{r}=0.38$ sig $5 \% \mathrm{n}=21$ \\
Region 2 & $\mathrm{PMP}=0.0577 \mathrm{AAR}+342.9241 \mathrm{r}=0.50 \operatorname{sig} 5 \% \quad \mathrm{n}=27$ \\
Region 3 & $\mathrm{PMP}=0.0854 \mathrm{AAR}+367.3290 \mathrm{r}=0.84 \operatorname{sig} 0.1 \% \quad \mathrm{n}=34$ \\
\hline
\end{tabular}




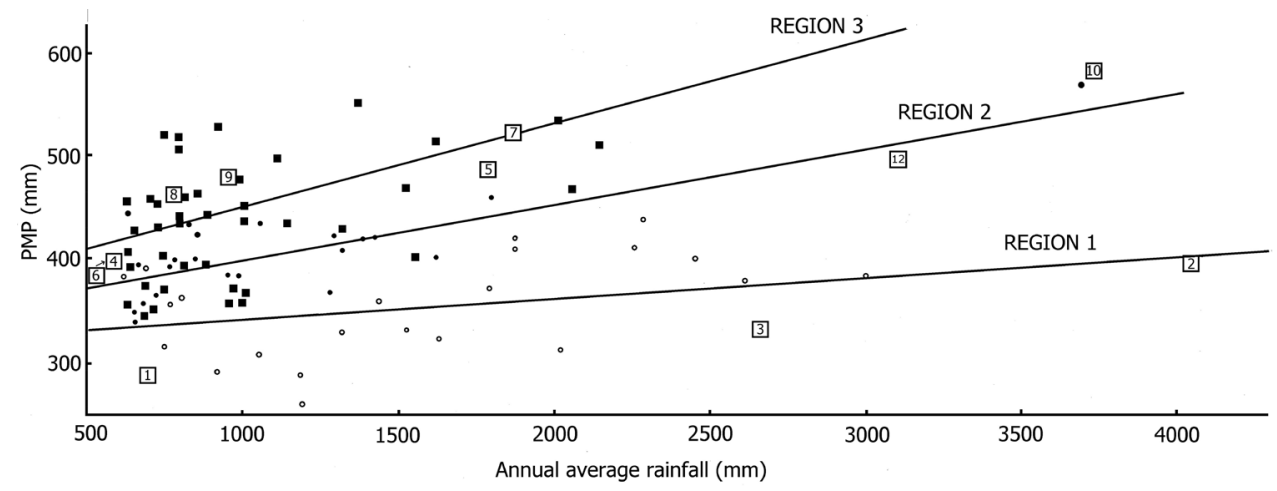

Figure 3. Relationship between annual average rainfall $(\mathrm{mm})$ and estimated PMP $(\mathrm{mm})$ for three regions in Britain Open circles region 1; closed circles region 2; squares region 3.

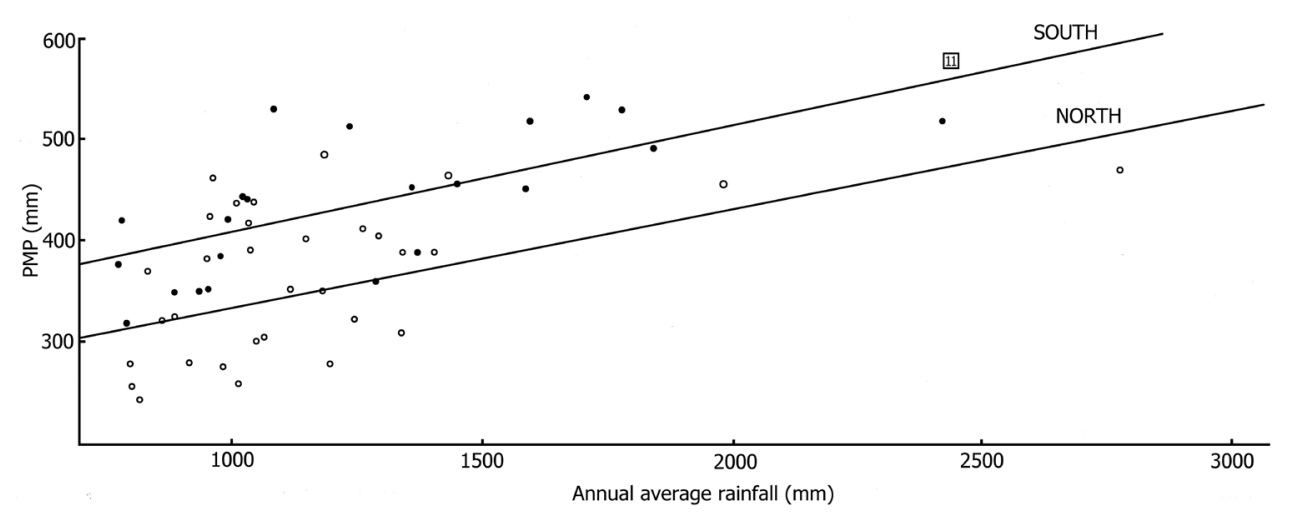

Figure 4. Relationship between annual average rainfall and PMP for two regions in Ireland Open circles North Ireland, closed circles South Ireland.

For Ireland a similar pattern of results is apparent (Figure 4). However, for the northern half values of PMP are about $300 \mathrm{~mm}$ for areas with $800 \mathrm{~mm}$ AAR, rising to about $470 \mathrm{~mm}$ for $2000 \mathrm{~mm}$ AAR. In the wettest areas of SW Ireland PMP can be as high as $600 \mathrm{~mm}$. The regression equations for Ireland are shown in Table 3.

The results of the storm maximisation are given in Table 6 and they have been included in Figure 3 and Figure 4. They all support the results of the regional frequency analyses. For example storms 1 - 3 are all close to the regression line for region 1 . Storms 4,10 and 12 are close to the regression line for region 2, while the remaining storms have some of the highest maximised rainfall depths. In Ireland the maximised Kippure storm compares well with the regression line for region South.

The next stage of the analysis was to produce an equation that links AAR and latitude (LAT) with PMP. The average latitude for each region was related to the slope of the regression and the regression constant. The results for Britain and Ireland are given in Table 4.

The results were combined to produce two equations for PMP (Table 5).

Using values of AAR and latitude and a correction for under recording of rainfall a new map of 24 hour PMP was produced (Figure 5). Lowest PMP val- 
ues are in Northern Ireland and Scotland, with the highest values in SW Ireland and the uplands of SW England and Wales. Values of PMP range from about $300 \mathrm{~mm}$ to over $550 \mathrm{~mm}$ in upland areas of Scotland, Wales, Northern England and Ireland. The results of the storm maximisation as given by Equation (1) are given in Table 6 and they support the results shown in Figure 5, with $r=0.94$ sig. $0.1 \%$. The root mean square error (RMSE) of the maximised rainfall and the value given in Figure $5=39.3 \mathrm{~mm}$.

Table 3. Regression equations for Ireland north and south of $53.5^{\circ} \mathrm{N}$.

PMP $($ south $)=0.1211 \mathrm{AAR}+293.2820 \mathrm{r}=0.70$ sig $0.1 \% \mathrm{n}=23$

$\operatorname{PMP}($ north $)=0.1067 \mathrm{AAR}+233.2081 \mathrm{r}=0.53$ sig $1 \% \mathrm{n}=30$

Table 4. Relationship between mean latitude (LAT) in the zones of Britain and Ireland, regression slope and constant.

\begin{tabular}{ccc}
\hline & \multicolumn{1}{c}{ Slope } & Constant \\
\hline Britain & $\mathrm{S}=-0.01136 \mathrm{LAT}+0.6691$ & $\mathrm{C}=-7.7060 \mathrm{LAT}+761.2386$ \\
Ireland & $\mathrm{S}=-0.0093 \mathrm{Lat}+0.6073$ & $\mathrm{C}=-27.4315 \mathrm{LAT}+1733.1478$ \\
\hline
\end{tabular}

Table 5. Regression equations for the estimation of PMP for Britain and Ireland.

\begin{tabular}{cc}
\hline Britain & PMP $=$ AAR $(-0.01136 \mathrm{LAT}+0.6691)+(-7.7060 \mathrm{LAT}+761.2386)$ \\
slope of regression & regression constant \\
Ireland & $\mathrm{PMP}=\mathrm{AAR}(-0.0093 \mathrm{LAT}+0.6073)+(-27.4315 \mathrm{LAT}+1733.1478)$ \\
\hline
\end{tabular}

Table 6. Storm events in the British Isles.

\begin{tabular}{lccccccc}
\hline \multicolumn{1}{c}{ Location } & Year & $\begin{array}{c}\text { Rainfall } \\
(\mathrm{mm})\end{array}$ & $\begin{array}{c}\text { Td deg } \\
\text { C }\end{array}$ & $\begin{array}{c}\text { Td } \\
\text { Maximum }\end{array}$ & MMF & $\begin{array}{c}\text { Maximised } \\
\text { rainfall }\end{array}$ & PMP Figure 5 \\
\hline 1. Inverness & 1915 & 179 & 11.2 & 16.5 & 1.6 & 292 & 345 \\
2. Cruadhach & 1954 & 257 & 7.2 & 12 & 1.57 & 403 & 420 \\
3. Loch Lomond & 1974 & 239 & 7 & 11 & 1.42 & 339 & 394 \\
4. Norfolk & 1912 & 218 & 13.9 & 21 & 1.83 & 399 & 430 \\
5. South Wales & 1929 & 211 & 7.2 & 16.4 & 2.34 & 494 & 564 \\
6. South Essex & 1968 & 210 & 12.4 & 19.5 & 1.88 & 395 & 435 \\
7. Exmoor & 1952 & 267 & 12.7 & 20.5 & 1.98 & 529 & 574 \\
8. Bruton & 1917 & 243 & 13.3 & 20 & 1.87 & 454 & 466 \\
9. Martinstown & 1955 & 355 & 16.1 & 20.5 & 1.46 & 518 & 489 \\
10. Honister & 2015 & 341 & 10.5 & 16 & 1.63 & 559 & 563 \\
11. Kippure & 1986 & 285 & 10 & 18 & 2.01 & 583 & 563 \\
\hline
\end{tabular}




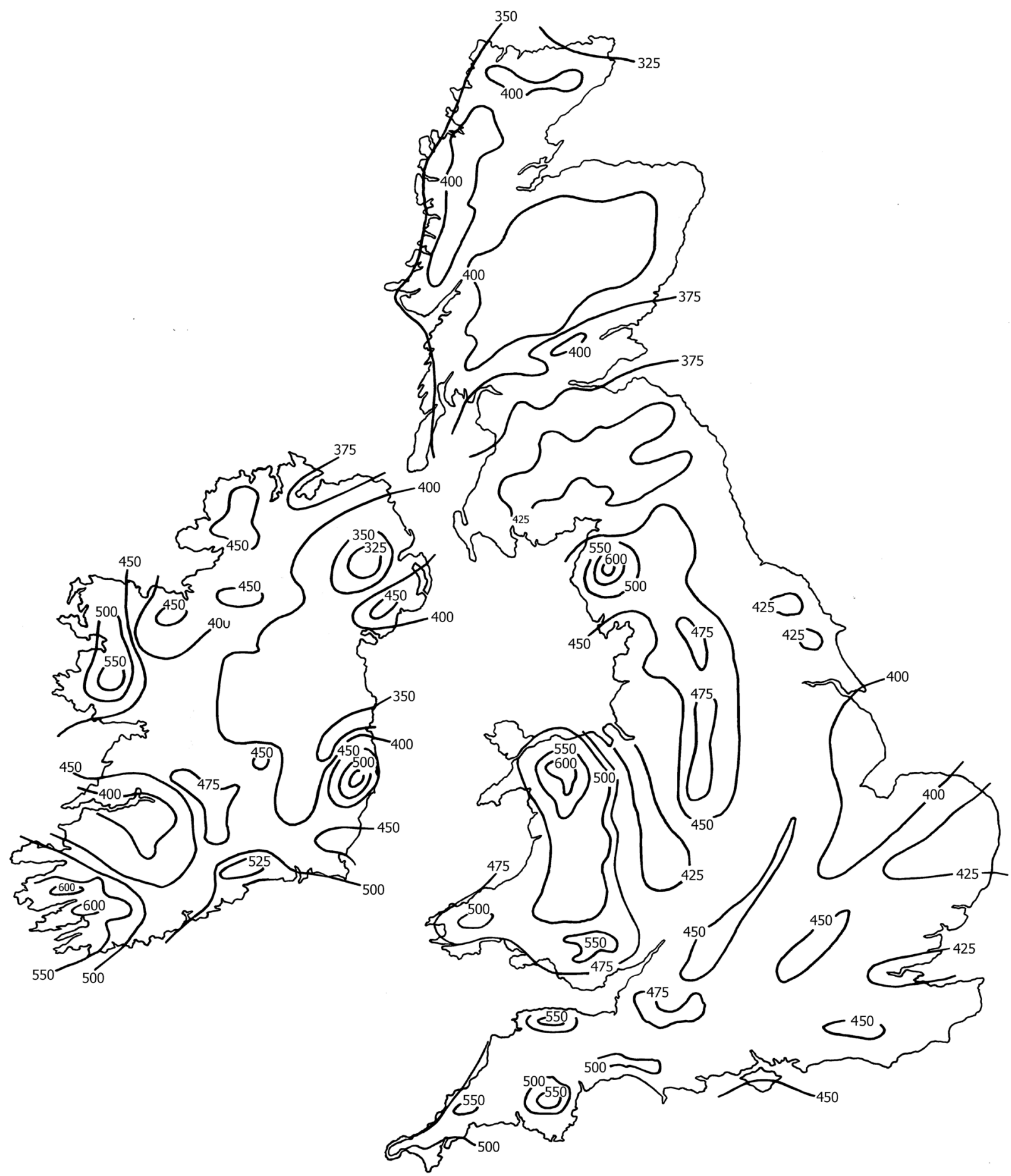

Figure 5. Distribution of 24 hour PMP ( $\mathrm{mm}$ ) for the British Isles.

\section{Implications for Dam Safety and the 1 in 10,000 Year Storm}

When compared with the Flood Studies Report (NERC, 1975) PMP the results of this paper show that 24-hour PMP has been underestimated for the whole of Britain by about $150-200 \mathrm{~mm}$. Over upland areas the difference is about 100 
$\mathrm{mm}$. The effect of relief is apparent over much of SW England and also Ireland. In contrast to this finding the FSR PMP shows little variation with relief, a fact which was shown to be in error following the August $25-26^{\text {th }}$ storm over the Wicklow Mountains in 1986 (Wallingford, 1996). The implication for dam safety is that all else being equal, values of the spillway design flood can be expected to need revising upwards by about $20 \%-40 \%$. Higher PMP values were found necessary when attempting to reproduce a 240 year historic flood frequency analysis for the upper Brue in Somerset UK for a dam safety study: the design flood was found to be more than double the original value of 240 cumecs (Black \& Veatch, 2005). The other contributing factors to the increasing estimate were higher percentage runoff and lower time to peak. The effect of a reduction of time to peak is due to rainfall intensity (Clark, 2004; Wass et al., 2008). Following the flood study the flood detention dam was given a major upgrading (Pether, 2010).

In recent years in the UK flood standards for dams have fallen into the Safety check flood and the Design flood, or the PMF and the 1 in 10,000 year event respectively (ICE, 2015). The effect of the higher estimates of PMP would be expected to affect lesser but nevertheless rare storm depths. This effect is shown in Table 7 where the results from two sites, storm duration, and three scales are shown.

The areal estimates of rainfall are based on the ARF's (Institute of Hydrology, 1999) and Clark (2012). In the latter report the lower areal rainfall reduction factors were based on the most serious storms in the UK whose rainfall in the central area is much more concentrated than those of Institute of Hydrology (1999) suggest. Even so, with this greater areal reduction in rainfall the depths of 1 in 10,000 year rainfall are still higher, with the exception of $6 \mathrm{hr}$ duration over an area of $20 \mathrm{~km}^{2}$ at Ogston Reservoir. Overall, the differences become bigger over smaller areas which is the scale covered by many dams in the UK. Clearly such results will leave the potential user with a choice which may result in either an over or under-design. The most obvious way to test the alternative results is to use them to estimate the PMF and then to compare the results with the envelope curve for floods which have occurred in Britain (Acreman, 1989). Thus the estimates of PMP were treated in exactly the same way in the non-linear flow model previously described (Clark, 2004, 2012). The online material of Clark (2019a) gives the details of the method, while the results are presented in Table 8.

Clearly the higher PMP has produced a PMF close to the envelope curve of historical floods. Although it could be argued that the runoff model used overestimated the PMF, the use of the lower rainfall has produced a PMF with a runoff rate less than half that indicated by actual events. Although there will be uncertainty with the historic flood estimates the overall weight of this evidence is in favour of the much greater estimate of the PMF. As an added perspective to the situation, a higher result using FEH13 rainfall can be obtained using FEH areal reduction factors, but as we have already seen these factors are much greater 
than those observed during extreme rainfall events. Thus it is important to get a realistic estimate for the right reasons.

Table 7. Estimates of 1 in 10,000 year $24 \mathrm{hr}$ and $6 \mathrm{hr}$ rainfall $(\mathrm{mm})$ at two sites and three different areas. $\mathrm{ARF}=$ area reduction factor.

\begin{tabular}{|c|c|c|c|c|c|c|}
\hline \multirow[b]{3}{*}{ Point } & & \multicolumn{5}{|c|}{24 hour duration $(\mathrm{mm})$} \\
\hline & \multicolumn{4}{|c|}{ FEH13 (Stewart et al., 2013) } & \multicolumn{2}{|c|}{ This paper } \\
\hline & & 2 year & 10,000 year & & 10,000 year & $\mathrm{PMP}^{*}$ \\
\hline \multirow[t]{2}{*}{ St Mawgan } & & 39 & 171 & & 299 & 500 \\
\hline & \multicolumn{2}{|c|}{$\operatorname{ARF}(1)$} & \multicolumn{3}{|c|}{$\operatorname{ARF}(2)$} & \\
\hline \multirow[t]{3}{*}{ Areal: } & $20 \mathrm{~km}^{2}$ & 0.966 & 165 & 0.83 & 256 & \\
\hline & $10 \mathrm{~km}^{2}$ & 0.973 & 166 & 0.874 & 267 & \\
\hline & $5 \mathrm{~km}^{2}$ & 0.978 & 167 & 0.914 & 278 & \\
\hline Point & & 2 year & 10,000 year & & 10,000 year & $\mathrm{PMP}^{*}$ \\
\hline Ogston Res. & & 41 & 192 & & 273 & 440 \\
\hline \multirow[t]{4}{*}{ Areal: } & $20 \mathrm{~km}^{2}$ & 0.966 & 185 & 0.83 & 235 & \\
\hline & $10 \mathrm{~km}^{2}$ & 0.973 & 187 & 0.874 & 244 & \\
\hline & $5 \mathrm{~km}^{2}$ & 0.978 & 188 & 0.914 & 260 & \\
\hline & & \multicolumn{5}{|c|}{6 hour duration $(\mathrm{mm})$} \\
\hline Point & & 2 year & 10,000 & & 10,000 year & $\mathrm{PMP}^{*}$ \\
\hline St Mawgan & & 23 & 135 & & 203 & 352 \\
\hline \multirow[t]{3}{*}{ Areal: } & $20 \mathrm{~km}^{2}$ & 0.943 & 127 & 0.72 & 155 & \\
\hline & $10 \mathrm{~km}^{2}$ & 0.955 & 149 & 0.782 & 165 & \\
\hline & $5 \mathrm{~km}^{2}$ & 0.964 & 130 & 0.854 & 178 & \\
\hline \multicolumn{7}{|l|}{ Point: } \\
\hline Ogston Res. & & 25 & 156 & & 190 & 318 \\
\hline \multirow[t]{3}{*}{ Areal: } & $20 \mathrm{~km}^{2}$ & 0.943 & 147 & 0.72 & 145 & \\
\hline & $10 \mathrm{~km}^{2}$ & 0.955 & 149 & 0.782 & 156 & \\
\hline & $5 \mathrm{~km}^{2}$ & 0.964 & 135 & 0.854 & 168 & \\
\hline
\end{tabular}

$y$ for PMP $=9.3826$ and for 2 year $=0.1891 ;{ }^{*}$ Based on $1 \mathrm{hr}$ PMP $=160 \mathrm{~mm}$ (Clark, 2009) and regression of Log duration (hours) and rainfall depth; (1) FEH volume 4 p. 45. (2) Clark (2012).

Table 8. Estimates of the PMF and runoff rates for a catchment in SW England $20 \mathrm{~km}^{2}$ with an average slope of $20^{\circ}$, and the runoff rate of the Extreme Catastrophic Flood (ECF), (Allard et al., 1960; Acreman, 1989).

\begin{tabular}{ccccc}
\hline & $6 \mathrm{hr}$ PMP & PMF m ${ }^{3} \cdot \mathrm{s}^{-1}$ & Runoff rate & ECF runoff rate $\mathrm{m}^{3} \cdot \mathrm{s}^{-1} \mathrm{~km}^{2}$ \\
\hline This paper & 352 & 378 & 18.9 & 17.8 \\
FEH13 & 213.5 & 153 & 7.7 & 17.8 \\
\hline
\end{tabular}




\section{Uncertainty of PMP Estimates}

In more recent years concern has been raised about the uncertainty of estimates of PMP (Salas et al., 2014). These have been summarised in Table 9.

The importance of PMP for dam safety assessments has been highlighted by Rakhecha \& Clark (1999); Stratz \& Hossain, (2014); Wickramasuriya \& Fernando (2012), while in the UK there has been one dam that has been upgraded as a result of using higher estimates of PMP than are generally accepted (Black \& Veatch, 2005).

The most important uncertainties in estimating PMP stem from the following:

1) There are no long term rainfall records that may include a fuller range of the natural variability of the existing climate. As time passes new record rainfall depths will be recorded making it difficult to distinguish between climate variability and change. Furthermore, an underestimate of the current PMP may be misinterpreted in the future when higher values are recorded as evidence of climate change.

2) There are not enough raingauges that can measure the distribution of storm rainfall in detail, much of which is lost, especially over high ground where there are even fewer gauges.

3) The existing records are incomplete especially during a severe storm such as at Boltby (Clark, 2008) where the gauge was flooded out from the nearby river.

4) Although the lack of a more dense network of gauges can be compensated by undertaking depth area analysis (Rakhecha \& Clark, 1999), this is rarely done with the result that PMP is seriously underestimated.

5) Measurement error especially in the case of out-splashing from the gauge (Cochrane, 1991) and the effects of turbulence on high ground where the runoff from rivers can be higher than the measured rainfall (Clark, 2016).

6) Uncertainty also stems from there being not enough extreme floods which could be used to test the estimates of PMP. In the case of the Upper Brue in East

Table 9. Uncertainties of PMP estimates.

\begin{tabular}{ll}
\hline Cause & Source \\
\hline Rise of atmospheric moisture & Abbs (1999) \\
$\begin{array}{l}\text { Non-linear relationshio between } \\
\text { dewpoint and temperature }\end{array}$ & Chen \& Bradley (2006) \\
No return period for PMP & Koutsoyiannis (1999), Papalexiou \& Koutsoyiannis (2006) \\
Uncertain Gumbel distribution & Papalexiou \& Koutsoyiannis (2013) \\
& Kunkel et al. (2013), Rastogi et al. (2017), Lee et al. (2016) \\
Climate change effects & Thanh Thuy et al. (2019), Rouhani \& Leconte (2020) \\
& Sarkar \& Maity (2020), Gangrade et al. (2018) \\
Climate variability & Salas et al. (2020) \\
Assessment of uncetainty & Micovic et al. (2015), Singh et al. (2018), Ben Alaya et al. (2018) \\
\hline
\end{tabular}


Somerset UK (Clark, 2014) which now has a 295 year historic flood record, the FEH 6-hour storm with $100 \%$ runoff only yields a flood of $327 \mathrm{~m}^{3} \cdot \mathrm{s}^{-1}$ which was almost equalled in 1768 (Clark, 1999). Furthermore, the flood of 1917 with a rainfall intensity of $25 \mathrm{~mm} \cdot \mathrm{hr}^{-1}$ gave a peak discharge of about $175 \mathrm{~m}^{3} \cdot \mathrm{s}^{-1}$ while the Martinstown storm of 1955 which took place $45 \mathrm{~km}$ to the south if transposed would have caused a flood that exceeded $330 \mathrm{~m}^{3} \cdot \mathrm{s}^{-1}$. By using a $6.5 \mathrm{hr}$ PMP storm of $345 \mathrm{~mm}$ as calculated using the results in this paper a PMF of $497 \mathrm{~m}^{3} \cdot \mathrm{s}^{-1}$ is produced. According to the historic flood frequency analysis this discharge has a rarity of about $10^{6}$ years. This leads to a brief discussion about the apparent uncertainty of safety standards which leaving aside the technical aspects of the estimation method, is the main use of PMP.

7) In the UK the threshold population for a reservoir safety study is ten persons (ICE, 2015) but there is uncertainty in the frequency of the probable maximum flood (PMF) - assumed to have been caused by the PMP - that it occurs at an acceptable level of risk. For example it is associated with a return period of 1 in $10^{5}$ years (ACDS, 1991); $10^{7}$ years (Ale, 1991, quoted in Hughes et al. 2000), and $10^{4}$ (Halpin, 2010). More recently (Environment Agency, 2013) gives an acceptable level of risk of 1 in $10^{6}$ years is associated with 100 deaths as a result of dam failure, and $10^{5}$ years for 10 deaths. This leads us to ask one question: given all the uncertainties which have already been mentioned above, should the minimum standard for saving human lives from dam break floods be increased to a minimum risk of 1 in $10^{6}$ years or even 1 in $10^{-7}$ years? If the answer is in the affirmative then much of the effort in uncertainty analysis would be better spent improving the hydrometric networks and more historic flood studies as already described.

8) The Hershfield method (Hershfield, 1961) for estimating PMP has been used in many studies but has not been tested against an actual storm event. For Mumbai in India it failed the test in July 2005 when $944 \mathrm{~mm}$ in 24 hours were recorded. prior to this the highest recorded storm was $575 \mathrm{~mm}$, while the IITM PMP Atlas (IITM, 1989) which was produced using the Hershfield method predicted a PMP for Mumbai of $700 \mathrm{~mm}$. Whatever allowance for uncertainty and uncertainty analysis, future storm events may override all these efforts. Finally, WMO (2009) clearly states that the Hershfield method produces results that are not as reliable as those produced by detailed meteorological analysis. In spite of this advice Sarkar \& Maity (2020) split the daily rainfall records of India into pre and post 1970 time periods and argued that a change of PMP between the two time periods as described using a modified Hershfield method was an indication of a change of climate, with the earlier period showing results similar to the PMP Atlas published by the IITM (1989). However, the new results are very similar to those of Rakhecha \& Clark (1999) where 10 out of the 11 storms that were maximised took place from 1880 to 1968 which is the time period when lower estimates of PMP according to Sarkar \& Maity (2020) were produced. Not only should the authors have carried out a full meteorological analysis but also consider if they have described climate variability instead of climate change. 


\section{Conclusion}

The estimates of PMP which have been presented are probabilistic and deterministic. Therefore considerable uncertainties exist with the results. Although there will always be uncertainties in the accuracy and coverage of rainfall measurements, storm dew point rarity and choice of storm rarity which may best describe values of PMP, much higher or lower results would produce estimates of the probable maximum flood (PMF) which either have been exceeded or fall outside of the extreme catastrophic flood of Allard et al. (1960), and Acreman (1989). It must always be remembered that raingauge data are essentially point measurements, and rainfall can vary considerably over short distances. Perhaps the greatest uncertainty is with the rainfall data since it can vary greatly over short distances in major storms and there are not enough raingauges to account for this. The methodologies employed involve a choice of storm rarity $\left(10^{6}\right.$ years), frequency distribution, and fitting procedure. The WMO method of storm maximisation also has arbitrary rules which can produce a range of values. At the same time the design engineer needs a single value from which the PMF is estimated and the size of dam spillways calculated. Over the years estimates of maximum rainfall and flood have tended to rise. This is mainly because a larger sample of rainfall data has been gathered. Similarly, extending a flood record beyond the era of measurements has shown that very significant floods have taken place during the $18^{\text {th }}$ and $19^{\text {th }}$ centuries. Higher estimates of the PMF will mean that the size of design floods will also increase. Typically there will be a $30 \%$ rise in the 1 in 100-year rainfall as a result of PMP increasing from $300 \mathrm{~mm}$ in the Flood Studies Report (NERC, 1975) to $500 \mathrm{~mm}$. For St. Mawgan in SW England a difference of $48 \mathrm{~mm}$ over an area of $5 \mathrm{~km}^{2}$ will lead to higher percentage runoff and a lower time to peak of the unit hydrograph (Clark, 2004).

Although several studies have suggested that estimates of PMP will increase in the future (Kunkel et al., 2013; Sarkar \& Maity, 2020) the existing ones that are normally used in the UK are too low so the apparent effect of a change of climate as described by higher results calculated more recently may not be correct. This stems from an insufficiency and even decreasingly dense raingauge network, without which an accurate description of the storm data base will be lacking. It is largely the difference in network density between Ireland and Britain (Clark 2019b) that helps to explain the low number of high rainfall events in Ireland.

Together with suitable areal reduction factors, a more realistic time to peak, and percentage runoff values the spillway design floods of many category A dams which are earth filled in the British Isles should now be reassessed. The results could be expressed in probability terms so that they can provide a risk based assessment for the greater protection of the public against a serious dam break incident.

\section{Acknowledgements}

The authors would like to thank the British Atmospheric Data Centre and Met 
Eireann for providing data on which this study is based, and the two referees whose comments helped us to improve the paper.

\section{Conflicts of Interest}

The authors declare no conflicts of interest regarding the publication of this paper.

\section{References}

Abbs, D. J. (1999). A Numerical Modelling Study to Investigate the Assumptions Used in the Calculation of Probable Maximum Precipitation. Water Resources Research, 35, 785-796. https://doi.org/10.1029/1998WR900013

Acreman, M. C. (1989). Extreme Historical UK Floods and Maximum Flood Estimation. Water and Environment Journal, 3, 404-412. https://doi.org/10.1111/j.1747-6593.1989.tb01546.x

Advisory Committee on Dangerous Substances (ACDS) (1991). Major Hazards Aspects of the Transport of Dangerous Substances. London: HMSO.

Afzali-Gorouth, Z., Bakhtiari, B., \& Qaderi, K. (2018). Probable Maximum Precipitation Estimation in a Humid Climate. Natural Hazards and Earth System Sciences, 18, 3109-3119. https://doi.org/10.5194/nhess-18-3109-2018

Ale, B. J. M. (1991). Risk Analysis and Risk Policy in the Netherlands and the EEC. Journal Loss Prevention in the Process Industries, 4, 58-64.

Allard, W., Glaspole, J., \& Wolf, P. O. (1960). Floods in the British Isles. Proceedings of the Institution of Civil Engineers, 15, 119-144. https://doi.org/10.1680/iicep.1960.11901

Austin, B. N., Cluckie, I. D., Collier, C. G., \& Hardaker, P. J. (1995). Radar-Based Estimation of Probable Maximum Precipitation and Flood. Report, Salford: Department of Environment by METSTAR and the Telford Institute.

Australian Bureau of Meteorology (2003). The Estimation of Probable Maximum Precipitation in Australia: Generalised Short-Duration Method (34 p). Australian Bureau of Meteorology.

Ben Alaya, M. A., Zwiers, F., \& Zhang, X. (2018). Probable Maximum Precipitation: Its Estimation and Uncertainty Quantification Using Bivariate Extreme Value Analysis. Journal of Hydrometeorology, 19, 679-694. https://doi.org/10.1175/JHM-D-17-0110.1

Black \& Veatch (2005). Bruton Flood Storage Reservoir: Report on Hydraulic and Hydrological Studies (40 p. + Appendices). Bridgwater: Environment Agency.

Casas, M. C., Rodriguez, R., Prohom, M., Gazquez, A., \& Redano, A. (2011). Estimation of Probable Maximum Precipitation in Barcelona (Spain). International Journal of Climatology, 31, 1322-1327. https://doi.org/10.1002/joc.2149

Charles, J. A., Tedd, P., \& Warren, A. (2011). Lessons from Historical Dam Incidents (159 p). DEFRA/EA.SC080046/R1.

Chavan, S. R., \& Srinivas, V. V. (2015). Probable Maximum Precipitation Estimation for Catchments in Mahanadi River System. Aquatic Procedia, 4, 892-299. https://doi.org/10.1016/j.aqpro.2015.02.112

Chen, L.-C., \& Bradley, A. A. (2006). Adequacy of Using Surface Humidity to Estimate Atmospheric Moisture Availability for Probable Maximum Precipitation. Water Resources Research, 42, W09410. https://doi.org/10.1029/2005WR004469

Chow, V. T. (1951). A General Formula for Hydrologic Frequency Analysis. Transactions of the American Geophysical Union, 32, 231-237. 
https://doi.org/10.1029/TR032i002p00231

Clark, C. (1983). Discussion of Gumbel's Extreme Value Distribution 1: A New Look. Journal of Hydraulic Engineering, 109, 644-646.

Clark, C. (1995). New Estimates of Probable Maximum Precipitation (PMP) in South-West England. Meteorological Applications, 2, 307-312. https://doi.org/10.1002/met.5060020403

Clark, C. (1999). The Great Flood of 1768 at Bruton, Somerset. Weather, 54, 108-113. https://doi.org/10.1002/j.1477-8696.1999.tb06436.x

Clark, C. (2002). Rainfall Estimates in Great Britain. International Water Power \& Dam Construction, 54, 18-26.

Clark, C. (2004). A Non-Linear Unit Hydrograph Model for Real Time Flood Forecasting below a Dam. International Water Power \& Dam Construction, 56, 20-26.

Clark, C. (2005). The Martinstown Storm 50 Years on. Weather, 60, 251-257. https://doi.org/10.1256/wea.58.05

Clark, C. (2008). Flash Floods-The Boltby Incident. International Water Power \& Dam Construction, 60, 30-37.

Clark, C. (2009). The Use of Local Data in Predicting and Estimating Extreme Floods. Proceedings of the International Conference on Water, Environment, Energy and Society (WEES-2009), New Delhi, 12-16 January 2009, 635-646.

Clark, C. (2012). Spillway Design Flood and Flood Volume Estimated Using the New Guide to Flood Estimation. In T. S. W. Wong (Ed.), Flood Risk and Flood Management (pp. 219-255). New York: Nova Science.

Clark, C. (2014). The Great Flood of 1726 at Bruton, Somerset. Weather, 69, 249-253.

Clark, C. (2015). A 247-Year Flood Record on the Upper Stour, Dorset. Weather, 70, 236-241. https://doi.org/10.1002/wea.2516

Clark, C. (2016). Reply to Stephen Burt's Comments on the Scarborough Storm and Flood. Weather, 71, 63-65. https://doi.org/10.1002/wea.2729

Clark, C. (2019a). How Rare Is That Storm or Flood? Weather, 74, 432-436. https://doi.org/10.1002/wea.3452

Clark, C. (2019b). The Value of Using Unofficial Measurements of Rainfall: The Dublin Storm and Flood of June 1963. Journal of Geoscience and Environment Protection, 7, 76-91. https://doi.org/10.4236/gep.2019.72006

Clark, C., \& Pike, W. S. (2007). The Bruton Storm and Flood after 90 Years. Weather, 62, 300-305.

Cochrane, N. J. (1991). The Halifax Storm: The Final Word-Perhaps! Weather, 46, 401-402.

Collier, C. G., \& Hardaker, P. J. (1995). Estimating Probable Maximum Precipitation Using a Storm Model Approach. Journal of Hydrology, 183, 277-306.

Desa, M. N., Noriah, A. B., \& Rakhecha, P. R. (2001). Probable Maximum Precipitation for 24-h Duration over Southeast Asian Monsoon Region-Selangor, Malaysia. Atmospheric Research, 58, 41-54. https://doi.org/10.1016/S0169-8095(01)00070-9

Environment Agency (2013). Guide to Risk Assessment for Reservoir Safety Management (Vol. 2). Report SC090001/R2, Flood and Coastal Erosion Risk Management Research and Development.

Faulkner, D., \& Benn, J. (2016). Reservoir Flood Estimation: Time for a Re-Think. BDS 19th Biennial Conference: Dams_Benefits and Disbenefits: Assets or Liabilities? Lancaster, 1-12. 
Gangrade, S., Kao, S. C., Naz, B. S., Rastogi, D., Ashfaq, M., Singh, N., \& Preston, B. L. (2018). Sensitivity of Probable Maximum Flood in a Changing Environment. Water Resources Res, 54, 3913-3936. https://doi.org/10.1029/2017WR021987

Halpin, E. (2010). Overview and Update on Flood Risk Management, Levee Safety, TGR and Portfolio Risk Management for Levee Systems. Exploration of Tolerable Risk Guidelines for the USACE Levee Safety Program, Washington DC, 17-18 March, 161 p.

Henderson-Sellers, A., \& Robinson, P. J. (1986). Contemporary Climatology (439 p). London: Longman.

Hershfield, D. M. (1961). Estimating the Probable Maximum Precipitation. Journal of the Hydraulics Division, 87, 99-106. https://doi.org/10.1061/JYCEAJ.0000651

Hiraga, Y., Iseri, Y., Warner, M. D., Frans, C. D., Duren, A. M., England, J. F., \& Kavvas, M. L. (2021). Estimation of Long-Duration Maximum Precipitation during a Winter Season for Large Basins Dominated to Atmospheric Rivers Using a Numerical Weather Model. Journal of Hydrology, 598, Article ID: 126224. https://doi.org/10.1016/j.jhydrol.2021.126224

Holley, D., Dent, J. E., \& Clark, C. (in press). Thunderstorms and Extreme Rainfall in South Norfolk $16^{\text {th }}$ August 2020: Part 2 Hydrological Response and Implications for Design Storm Guidance. Weather.

Hughes, A. et al. (2000). Risk Management for UK Reservoirs (213 p). CIRIA Report No C542, London: CIRIA.

ICE (1933). Interim Report of the Committee on Floods in Relation to Reservoir Practice (42 p). Institution of Civil Engineers.

ICE (1960). Floods in Relation to Reservoir Practice. Reprint of the 1933 Report with Additional Data on Flood Recorded in the British Isles between 1932 and 1957 (66 p). London: Institution of Civil Engineers.

ICE (2015). Floods and Reservoir Safety (4th ed., 71 p). London: ICE.

Indian Institute of Tropical Meteorology (1989). Probable Maximum Precipitation Atlas. Pune: IITM.

Institute of Hydrology (1999). Flood Estimation Handbook. Wallingford: Institute of Hydrology.

Ishida, K., Kavvas, M. L., Jang, S., Chen, Z. Q., Ohara, N., \& Anderson, M. L. (2015). Physically Based Estimation of Maximum Precipitation over Three Watersheds in Northern California: Relative Humidity Maximization Method. Journal of Hydrologic Engineering, 20, 7 p. https://doi.org/10.1061/(ASCE)HE.1943-5584.0001175

Klemes, V. (2000). Tall Tales about Tails of Hydrological Distributions 1. Journal of Hydrologic Engineering, 5, 227-231. https://doi.org/10.1061/(ASCE)1084-0699(2000)5:3(227)

Koutsoyiannis, D. (1999). A Probabilistic View of Hershfield's Method of for Estimating Probable Maximum Precipitation. Water Resources Research, 35, 1313-1322. https://doi.org/10.1029/1999WR900002

Kunkel, K. E., Karl, T. R., Easterling, D. R., Redmond, K., Young, J., Yin, X., \& Hennon, P. (2013). Probable Maximum Precipitation and Climate Change. Geophysical Research Letters, 40, 1402-1408. https://doi.org/10.1002/grl.50334

Lee, O., Park, O., Kin, E. S., \& Kim, S. (2016). Projection of Korean Probable Maximum Precipitation under Future Climate Change Scenarios. Advances in Meteorology, 2016, Article ID: 3818236. https://doi.org/10.1155/2016/3818236

Lemperiere, F. (1993). Dams That Have Failed by Flooding: An Analysis of 70 Failures. International Water Power \& Dam Construction, 45, 19-24. 
Lowing, M. J., \& Law, F. M. (1995). Reconciling Flood Frequency Curves with the Probable Maximum Flood. British Hydrological Society 5th National Hydrology Symposium, Edingburgh, 4-7 September 1995.

Micovic, Z., Shaefer, M. G., \& Taylor, G. H. (2015). Uncertainty Analysis for Probable Maximum Precipitation Estimates. Journal of Hydrology, 521, 360-373.

https://doi.org/10.1016/j.jhydrol.2014.12.033

Nathan, R., Jordan, P., Scorah, M., Lang, M., Kuczera, G., \& Schaefer, M. (2016). Estimating the Exceedance Probability of Extreme Rainfall up to the Probable Maximum Precipitation. Journal of Hydrology, 543, 706-720.

https://doi.org/10.1016/j.jhydrol.2016.10.044

NERC (1975). Flood Studies Report. London: Meteorological Office.

Papalexiou, S. M., \& Koutsoyiannis, D. (2006). A Probabilistic Approach to the Concept of Probable Maximum Precipitation. Advances in Geosciences, 7, 51-54. https://doi.org/10.5194/adgeo-7-51-2006

Papalexiou, S. M., \& Koutsoyiannis, D. (2013). Battle of Extreme Value Distributions: A Global Survey on Extreme Daily Rainfall. Water Resources Research, 49, 187-201. https://doi.org/10.1029/2012WR012557

Pether, R. (2010). Design and Construction of Improvement Works at Bruton Flood Storage Reservoir, Somerset. Dams \& Reservoirs, 20, 33-38. https://doi.org/10.1680/dare.2010.20.1.33

Pollock, M. D., O’Donnell, G., Quinn, P., Dutton, M., Black, A., Wilkinson, M. E. et al. (2018). Quantifying and Mitigating wind Induced Undercatch in Rainfall Measurements. Water Resources Research, 54, 3863-3875.

https://doi.org/10.1029/2017WR022421

Rakhecha, P. R., \& Clark, C. (1999). Revised Estimates of One-Day Probable Maximum Precipitation (PMP) for India. Meteorological Applications, 6, 343-350. https://doi.org/10.1017/S1350482799001280

Rakhecha, P. R., \& Kennedy, M. R. (1985). A Generalised Technique for the Estimation of Probable Maximum Precipitation in India. Journal of Hydrology, 78, 345-359. https://doi.org/10.1016/0022-1694(85)90112-X

Rastogi, D., Kao, S.-C., Ashfaq, M., Mei, R., Kabela, E. D. Gangrade, S., Naz, B. S., Preston, B. L., Singh, N., \& Anantharaj, V. G. (2017). Effects of Climate Change on Probable Maximum Precipitation: A Sensitivity Study over the Alabama-Coosa-Tallapoosa River Basin. Journal of Geophysical Research: Atmospheres, 122, 4808-4828. https://doi.org/10.1002/2016JD026001

Rodda, J. C., \& Dixon, H. (2012). Rainfall Measurement Revisited. Weather, 67, 131-135. https://doi.org/10.1002/wea.875

Rodda, J. C., \& Smith, S. W. (1986). The Significance of the Systematic Error in Rainfall Measurements for Assessing Wet Deposition. Atmospheric Environment, 20, 1059-1064. https://doi.org/10.1016/0004-6981(86)90293-3

Rouhani, H. M., \& Leconte, R. (2020). Uncertainties of Precipitable Water Calculations for PMP Estimates in Current and Future Climates. Journal of Hydrologic Engineering, 25. https://doi.org/10.1061/(ASCE)HE.1943-5584.0001877

Salas, J. D., Anderson, M. L., Papalexiou, S. M., \& Frances, F. (2020). Probable Maximum Precipitation and Climate Variability and Change: A Review. Journal of Hydrologic Engineering, 25. https://doi.org/10.1061/(ASCE)HE.1943-5584.0002003

Salas, J. D., Gavilan, G., Salas, F. R., Julien, P. Y., \& Abdullah, J. (2014). Uncertainty of the PMP and PMF. In S. Eslamain (Ed.), Handbook of Engineering Hydrology. Vol. 3, Modelling, Climate Change and Variability (pp. 577-603). Boca Raton, FL: CRC Press. 
Sarkar, S., \& Maity, R. (2020). Increase in Probable Maximum Precipitation in a Changing Climate over India. Journal of Hydrology, 585, Article ID: 124806.

https://doi.org/10.1016/j.jhydrol.2020.124806

Singh, A., Singh, V. P., \& Byrd, A. R. (2018). Computation of Probable Maximum Precipitation and Its Uncertainty. International Journal of Hydrology, 2, 504-514. https://doi.org/10.15406/ijh.2018.02.00118

Stewart, E. J., Jones, D. A., Svensson, C., Morris, D. G., Dempsey, P., Dent, J. E., Collier, C. G., \& Anderson, C. W. (2013). Reservoir Safety-Long Return Period Rainfall. DEFRA R \& D Technical Report WS 194/2/39/TR.

Stratz, S. A., \& Hossain, F. (2014). Probable Maximum Precipitation in a Changing Climate: Implications for Dam Design. Journal of Hydrologic Engineering, 19, Article ID: 06014006. https://doi.org/10.1061/(ASCE)HE.1943-5584.0001021

Thanh Thuy, L. T., Kawagoe, S., \& Sarukkalige, R. (2019). Estimation of Probable Maximum Precipitation at Three Provinces in Northeast Vietnam Using Historical Data and Future Climate Change Scenarios. Journal of Hydrology: Regional Studies, 23, Article ID: 100599. https://doi.org/10.1016/j.ejrh.2019.100599

Wallingford, H. R. (1996). The 1986 Flood of Little Bray(26 p). Report EX 3429.

Wass, P., Lindsay, D., \& Faulkner, D. S. (2008). Flash Flood! A Lucky Escape for 10,000 Bikers. BHS 10th National Hydrology Symposium, Exeter.

Wickramasuriya, S. S., \& Fernando, W. C. D. K. (2012). Challenges in Dam Safety and Extreme Rainfall in Relation to Sri Lanka. Engineer, 35, 39-49.

https://doi.org/10.4038/engineer.v45i1.6948

Wiesner, C. J. (1970). Hydrometeorology (232 p). London: Chapman \& Hall.

WMO (2009). Manual for Estimating Probable Maximum Precipitation (3rd ed., 259 p). WMO No. 1045. 